DOI:10.17951/h.2020.54.1.77-88

\begin{tabular}{lcc}
\hline \multicolumn{3}{c}{ A N N A L E S } \\
UNIVERSITATIS MARIAE CURIE-SKŁODOWSKA \\
LUBLIN - POLONIA \\
VOL. LIV, 1 & SECTIOH H \\
\hline
\end{tabular}

\author{
ANNA PYKA \\ anna.pyka@ue.katowice.pl \\ University of Economics in Katowice. Faculty of Finance and Insurance \\ 501 Maja St., 40-287 Katowice \\ ORCID ID: https://orcid.org/0000-0002-1354-0992

\section{An Evaluation of the Technical Efficiency of the Selected Commercial Banks with the Usage of the CCR-DEA Model under the Conditions of Acquisitions in the Banking Sector}

Keywords: bank; efficiency; Data Envelopment Analysis model (DEA); Charnes, Cooper, and Rhodes model (CCR)

JEL: C61; G21; M210

How to quote this paper: Pyka, A. (2020). An Evaluation of the Technical Efficiency of the Selected Commercial Banks with the Usage of the CCR-DEA Model under the Conditions of Acquisitions in the Banking Sector. Annales Universitatis Mariae Curie-Skłodowska, sectio H-Oeconomia, Vol. 54, No. 1.

\footnotetext{
Abstract

The aim of this article is to evaluate the technical efficiency of the chosen commercial banks, which in the years 2014-2016 were participants in acquisitions in the banking sector, with the usage of the Data Envelopment Analysis (DEA) model. The DEA model was modified through reshaping the linear form using the Charnes, Cooper, and Rhodes (CCR) model, which is aimed at expenditures. Particular attention was paid to the impact of acquisitions in the banking sector on the improvement or deterioration of the technical efficiency of banks that act as acquiring banks.
} 


\section{Introduction - the significance of efficiency in the activity of a commercial bank}

Commercial banks are specialised institutions of the financial market founded on the basis of licenses from the proper supervision authorities. These banks deal with servicing and organising money circulation in the economy and are the basic organisational units, in addition to the units of the real zone. It could even be assumed that commercial banks are specific forms of companies. This specific nature is noticeable in the formal-legal zone and in the functions they perform in the economy. They are characterised by different rules of accountancy and reporting (Pyka, 2015, p. 219; Nawrocki \& Jabłoński, 2011, pp. 33-64). Nevertheless, many properties of commercial banks make it possible to analyse these economic units as companies. Similar to companies, banks play a variety of roles simultaneously: they are subjects of economic activity, they actively participate in the market, they have a significant influence on social relationships, and they combine resources, means, and processes (Marek \& Białasiewicz, 2008, p. 25). What connects companies and commercial banks is the activity aimed at gaining profit from the action undertaken. Accordingly, this refers to seeking profit as an element of market value (Gradon, 2016, pp. 192-193, 209-213; Michalak, 2016, p. 318).

Since one of the aims of the functioning of a company (or a bank) is the maximisation of profit (as a condition of the growth of market value), it seems proper to consider how this profit gaining is translated into the efficiency (productivity) of that activity. Frequently, the maximisation of profit (as an effect of the activity) is placed on par with the minimisation of costs. More precisely, reaching a particular goal is combined with the lowest costs possible, which proves the rationality of actions performed by a company (or by a bank) and is related to the notion of efficiency (Adamik, 2011, pp. 21-27).

The contemporary sector of commercial banks is undergoing significant quantitative and qualitative changes. The processes of bank consolidation and the re-Polonisation of the sector are accompanied by the processes of fusion and acquisition. In the area of qualitative changes, the main premise amounts to the growing financial demands of the clients, the growing competition on the market of financial services, and the changes in the preferences of the clients. All the aforementioned elements cause banks to monitor the efficiency of their actions to meet the demands of both the market and clients (Szelągowska \& Posacka, 2006, p. 137; Jonek-Kowalska \& Zieliński, 2017, pp. 1294-1304).

The aim of this article is to evaluate the technical efficiency of the following banks: PKO BP SA, Alior Bank SA, and Pekao SA. In the years 2014-2016, these banks took part in acquisitions on the banking market. The author is aware that the subject of the analysis is made up of a relatively small group of banks, and the analysis period only covers 4 years. However, from the point of view of takeovers in the banking market in the selected period, these were the key market transactions directly affecting the banking sector. The research sample - due to the number of 
takeover transactions in the analysed period (2014-2016) and on the scale of operations - can be considered representative. The analytic tool employed below is the CCR-DEA model, used as a device to support decision-making processes. This analysis has been carried out using the CCR model, which is aimed at expenditures. Particular attention has been paid to either the improvement or the deterioration of the technical efficiency of the banks acting as "acquiring" entities in the transactions of acquisition on the banking market.

\section{The usefulness of the CCR-DEA model in assessing the technical efficiency of economic units}

The notion of efficiency can be defined in a variety of ways, depending on the information a particular unit needs and the type of activity in which it is engaged ${ }^{1}$ (Nawrocki, 2015, pp. 229-234). Economic efficiency is always a quantitative category which describes the degree of fulfilling economic goals (Czyżewski \& Smędzik, 2010, p. 61).

Researches concerning efficiency in economic sciences are mainly concerned with the optimisation of resource allocation. Among other things, technical and financial types of efficiency are underlined, the latter being a basis for evaluations and conclusions concerning the financial situation of a unit based upon its financial report (Capiga, 2009, p. 45).

It is presently pointed out that traditional methods of measuring efficiency, including an envelopment analysis method - also referred to as a method of frontier data analysis or a method of analysing frontier efficiency, one of the most used ratio analysis methods (financial efficiency) - are not sufficient for a detailed efficiency analysis. Thus, the popularity of other measuring methods, including the nonparametric ones, keeps growing. One of these is called "data envelopment analysis" (DEA) (Stoła, 2011, p. 142). Popular data tools are employed to measure the technical efficiency of a unit's functioning. It is used to assess units such as financial institutions, schools, universities, health-care centres, and non-profit organisations (Domagała, 2007, p. 22).

The DEA method is classified as belonging to benchmarking methods. It is employed to make a comparison between the efficiency of the analysed object (a decision-making unit, DMU) and benchmark efficiency (Nowak \& Matuszyk, 2014, p. 115). The unit for which the ratio of relative efficiency amounts to $100 \%$ is an efficient object,

1 Efficiency, as a notion referring to the efficiency of a bank, can be viewed from many viewpoints, including: a) technical efficiency - concerning the management of costs, b) income efficiency assuming the maximising of the profit with stable prices and a given value of expenditures and effects, c) cost efficiency which concerns determining whether a given value of effect has been reached at the lowest costs possible, d) organisation efficiency - referring to the degree of realising the bank's goals, e) financial efficiency - the financial results achieved, f) general efficiency - referring to the technical and allocative efficiency (Capiga, 2009, p. 45). 
which gains $100 \%$ of the effects with the optimal use of the expenditures. Nonetheless, it should be underlined that in any economic reality, there appear much more complicated cases, since the units described are more than one expenditure and one effect. Therefore, out of many available DEA models, only one should be selected to calculate the relative efficiency coefficient and establish the benchmark for ineffective units. The DEA method belongs to nonparametric methods and does not assume the estimation of parameters. The measure of relative efficiency in the DEA method is defined as a quotient of the weighted sum of effects and the weighted sum of expenditures (Nowak \& Matuszyk, 2014, p. 115). Calculating the efficiency coefficient involves solving a linear programming problem for each DMU. The decision variables in the model are multipliers (weights). These multipliers show the significance of particular expenditures and effects (Nowak \& Matuszyk, 2014, p. 115).

The above-mentioned method can be modified by transforming it to a linear shape, depending on the selected option - expenditure-oriented or effect-oriented. Two models are used for this purpose: the CCR model (by Charnes, Cooper, and Rhodes) and the BCC model (by Banker, Charnes, and Cooper). The former model is expenditure-oriented and its purpose is to minimalise expenditures while keeping a stable level of effects. The analysed DMU is effective if the relative efficiency coefficient equals 1 . This means that expenditures cannot be reduced any further to achieve a given level of effects. The inefficiency of a unit occurs when the relative efficiency coefficient equals less than 1 . Then, there is a possibility to reduce the expenditures at a stated level of effects. Sufian and Habibullah (2009, pp. 210-217) indicated that the CCR model presupposes no significant relationship between the scale of operations and the efficiency by assuming constant returns to scale. The constant return to scale assumption is only justifiable when all DMUs are operating at an optimal scale.

The latter model is the effect-oriented BCC model. It is aimed at maximising the effects. The efficiency of a DMU means that it reaches the greatest effects at a stable level of expenditures (Nowak \& Matuszyk, 2014, p. 116).

The CCR-DEA model involves a few assumptions concerning the variables introduced into the research. These are as follows: the character of analysed objects must be homogenous or nearly homogenous, the growth of amounts considered as effects must be positively evaluated concerning the purpose of analysing objects (maximants), while the growth of amounts considered as expenditures (minimants) for a given level of effects is negatively evaluated. The measure of relative efficiency using the CCR-DEA model can be represented in terms of Formula 1.

$$
P(x, y)=\min \{x \geq X \lambda, y \leq Y \lambda, e \lambda=1, \lambda \geq 0\}
$$

Where:

$P$ - the measure of efficiency

$x$ - the vector of expenditures of a particular DMU

$X$ - the matrix of expenditures of all the analysed DMUs

$y_{-}$the vector of effects of a particular DMU 
$Y$ - the matrix of effects of all the analysed DMUs

$\lambda$ - multipliers which are decision variables - coefficients of a linear combination showing the optimal combination of expenditures

$e \lambda$ - the sum of coefficients of a linear combination - the measure of efficiency

The issue of the CCR-DEA model is a problem of linear programming and it involves choosing economic objects transforming the expenditures $X_{1}, X_{2}, \ldots, X_{N}$ into the results $Y_{1}, Y_{2}, \ldots, Y_{R}$ and determining their relative efficiency coefficient. Therefore, one should define:

I. Data - the amounts/values of expenditures and results in particular objects of an examined society,

II. Decision variables - multipliers,

III. The function of the goal - minimalisation of the expenditure level multiplier $\theta \rightarrow \min$,

IV. Limiting conditions:

a) the expenditures of common technology $X \lambda$ are smaller than expenditures $x$ approved by the analysed unit,

b) the results of common technology $Y \lambda$ are larger than results $y$ achieved by a given unit,

c) the expenditure multiplier $\theta$ is larger than 0 , while the sum of coefficients is a linear combination - the measure of efficiency $e \lambda$ is larger than 1 .

Solving the problem for a given DMU shows the significance of particular expenditures and achieved results, along with the measure of efficiency. The measure of efficiency $=1$ is considered as the benchmark efficiency. As already mentioned, due to this measure, it is possible to compare the efficiency of units in a given society.

\section{A characteristic of analysing the technical efficiency of selected commercial banks under the conditions of acquisitions in the banking sector}

The banks that participated in acquisitions in the banking sector in the years 2014-2016 are subjected to analysis. These include PKO BP SA, Alior Bank SA, and Pekao SA. The first of these banks - PKO BP SA - was a unit acquiring Nordea Bank Polska SA in April 2014 (approximately 2,000 employees). This acquisition aligned with realising the strategy of PKO BP SA for the years 2013-2015, where acquisitions and alliances were supposed to constitute one of the main development leverages. A fusion of those banks was also a consequence of the strategic decision of the previous stock-holder of the acquired bank, the Scandinavian Nordea AB, which decided to limit its activity on the Polish market ${ }^{2}$. The first leg of the integration ended

\footnotetext{
2 According to PKO, Nordea Bank Polska was the most desired in terms of the business profile, the network of branches and the ability to efficiently integrate. Moreover, Nordea Bank had good quality assets.
} 
on October 31, 2014 in a legal fusion of both banks. Since that fusion, Nordea Bank Polska stopped functioning as a separate unit, while PKO Bank Polski took over all the Nordea Bank Polska contracts with the clients (over 300,000). On April 20, 2015, an operational fusion occurred - both banks constituted one "organism" for the clients, who could utilise all the functions of the merged bank. The acquisition of Nordea Bank by PKO triggered a change of data and financial indicators in this bank. A selected number of these are presented in Table 1.

Table 1. Data and financial indicators of PKO BP SA

\begin{tabular}{|l|r|r|r|r|r|r|}
\hline \multirow{2}{*}{$\begin{array}{c}\text { Consolidated } \\
\text { financial data } \\
\text { (billion PLN) }\end{array}$} & 2012 & 2013 & 2014 & 2015 & 2016 & 2017 \\
\cline { 2 - 8 } & $\begin{array}{c}\text { Before the acquisition of } \\
\text { Nordea Bank }\end{array}$ & \multicolumn{5}{|c|}{ After the acquisition of Nordea Bank } \\
\hline Assets & 193.2 & 199.2 & 248.7 & 266.9 & 285.6 & 296.9 \\
\hline Net credits & 143.5 & 149.6 & 179.5 & 190.4 & 189.0 & 186.9 \\
\hline Deposits & 146.2 & 151.9 & 174.4 & 195.8 & 209.3 & 222.5 \\
\hline Owner's equity & 24.4 & 25.2 & 27.6 & 30.3 & 32.6 & 36.3 \\
\hline Net profit & 3.7 & 3.2 & 3.3 & 3.0 & 3.7 & 3.7 \\
\hline
\end{tabular}

Source: Author's own study based on PKO BP financial reports for 2012-2017 (www.1).

The assets of PKO BP SA after the acquisition of Nordea (2014) grew to the level of almost PLN 249 billion, which included the growth of credits to almost PLN 180 billion (see Table 1). The growth of credit value by PLN 30 billion in 2014 in relation to 2013 caused a growth in the participation in the market by over $1 \%$ (to nearly $18 \%$ ).

The second analysed bank is Alior Bank - one of the newest banks in Poland, functioning in the banking sector since 2008. In 2015, Alior Bank acquired Meritum Bank ICB SA ${ }^{3}$, while in November 2016, it took over BPH SA ${ }^{4}$. That transaction was a result of strategic decisions of the previous owner of BPH SA - General Electric decided to withdraw from a banking focus on its fundamental business.

After the acquisition of Meritum Bank, the general value of assets of Alior Bank grew by $25 \%$ in relation to 2014 , namely to PLN 40 billion. After the acquisition of BPH SA (its selected part - without mortgage loans, both in PLN and in foreign currencies), the general value of assets of Alior Bank grew (by the end of 2016) to over PLN 61 billion (and it became the $9^{\text {th }}$ bank in Poland in terms of gathered assets) $)^{5}$. The number of clients grew to 3.5 million and the deposit bases grew to PLN 51.4 billion, while the credit portfolio grew to PLN 46.3 billion (see Table 2).

3 These banks were fused as a result of Alior Bank acquiring 12,382,746 shares of Meritum Bank ICB in February 2015, which represented $97.7 \%$ of its owner's capital. The value of the transaction was PLN 352.5 million, while the estimated cost of fusion was PLN 50 million.

${ }_{4}$ The operational fusion occurred on March 25, 2017. The financial condition of BPH SA at that time was poor (repair programme was in force), while the participation in the frank credit services was considerable. The value of purchasing $87.23 \%$ of shares of the basic banking activity of BPH SA by Alior Bank was PLN 1.225 billion.

5 In June 2016, the value of assets was PLN 47 billion, while BPH possessed PLN 15 billion. 
In the case of Pekao SA, the acquisition had a purely owner-like significance - in June 2017, PZU SA, together with the Polish Development Fund (PDF), took over nearly $1 / 3$ of the capital owned by Pekao SA ${ }^{6}$. There was no fusion with another bank. Consequently, there were no changes in the amount of resources (expenditures) or effects which might have influenced the efficiency of the bank. Similarly, the takeover of shares by PZU and PDF did not affect the area of expenditures and effects treated as inputs to a DEA analysis. This was strongly and strategically justified, though, since the strategy of PZU SA for the years 2016-2020 assumed the creation of a strong banking group with a joint value of assets over PLN 140 billion. This bank was and remained the second bank in Poland in terms of assets and owner's capital, and there was a possibility of making a large financial group. Additionally, the participation of Pekao SA in the banking sector was significant and its development potential was high (the first acquisition by PZU SA was buying $25.19 \%$ of shares in the owner's capital of Alior Bank SA) 7 . The acquisition of Alior Bank SA and Pekao SA by PZU SA visualised the scale of re-Polonisation, a phenomenon occurring in the Polish banking sector. This also formed a basis for the consolidation of the national banking sector (Pyka, Cichy, Nocoń, \& Pyka, 2018, p. 187).

Turning now to data characterising the analysed banks and using the CCR-DEA model, it is noteworthy that the first phase of research entails the selection of data. No assumptions concerning a linear correlation between selected variables (in this case, expenditures and results) is considered an advantage of this method. Accordingly, the choice only depends on the researcher. For example, Gospodarowicz (2002, p. 91) assumes the sum of rate costs and operation costs as expenditures, and the values of deposits and credits as effects. Guzik (2009, p. 62) categorises expenditures as fixed assets, inputs, costs of activity, and employment, and results as credits and interbank accounts. Kopiński and Porębski (2015, p. 263), in turn, select assets and the number of employees as expenditures and deposits, credits, the number of clients, and the capital adequacy ratio are results in their analysis. Olesen, Petersen, and Podinovski (2017, pp. 640-655) also used the ratio (capital adequacy ratio) as an output.

To achieve the aims of the analysis presented in this article, variables such as assets and the number of employees are considered expenditures, whereas deposits, credits, the number of clients, and the capital adequacy ratio are viewed as results. Such assumptions are not consistent with Golany and Roll (1989, pp. 237-250).

6 Signing the transaction documents concerning the acquisition took place on December 8, 2016. Simultaneously, legally required applications were delivered to the Financial Oversight Commission and the Office of Competition and Consumer Protection. On June 7, 2017, the acquisition was completed. The investors agreed to purchase the $32.8 \%$ of shares belonging to Pekao SA from UniCredit Group. PZU Group purchased $20 \%$ of shares, while PDF bought $12.8 \%$ of shares. The share price being PLN 123 , the value of the whole transaction amounted to PLN 10.6 billion, where PZU SA paid PLN 6.5 billion, while PFR - PLN 4.1 billion.

7 This occurred on the basis of a contingent contract signed on May 30, 2015 through buying a joint number of 18,318,473 shares, i.e. 17,818,473 shares of Alior Bank SA by Alior Lux S.à.r.1. \& Co. S.C.A and 500,000 shares from Alior Polska Ltd. 
They established a rule of thumb that the number of units should be at least twice the number of inputs and outputs considered. However, in this article, authors used two input and four output variables in the DEA model. Thus, the number of inputs and outputs is not aligned with the Golany and Roll rule. The data are presented in Table 2. An analysis of the data from 2014-2017 included in Table 2 leads to the claim that the main tendency in analysed banks was increasing the participation in the market of bank assets and decreasing the employment, although in the early stages of acquisitions, the employment may have temporarily grown (e.g., in Alior Bank). In the period under analysis, all the banks, as a result of acquisitions and organic growth, noted a growth of the results selected for the analysis - the number of clients, the value of deposits, credits and the capital adequacy ratio.

Table 2. The value of expenditures and results for DMUs in the years 2014-2017

\begin{tabular}{|c|c|c|c|c|}
\hline \multicolumn{5}{|c|}{ Year 2014} \\
\hline \multicolumn{2}{|r|}{ Specification } & PKO BP & Pekao & Alior \\
\hline \multirow{2}{*}{ Expenditures } & number of employees & 26,078 & 18,765 & 6,637 \\
\hline & bank's assets (PLN million) & 248,700 & $164,322.8$ & $30,167.6$ \\
\hline \multirow{4}{*}{ Results } & value of deposits (PLN million) & 174,400 & 125,533 & 24,428 \\
\hline & value of credits (PLN million) & 179,500 & $100,330.6$ & 23,648 \\
\hline & number of clients & $8,894,000$ & $4,888,771$ & $2,576,000$ \\
\hline & capital adequacy ratio & $13.00 \%$ & $17.10 \%$ & $12.80 \%$ \\
\hline \multicolumn{5}{|c|}{ Year 2015} \\
\hline \multicolumn{2}{|r|}{ Specification } & PKO BP & Pekao & Alior \\
\hline \multirow{2}{*}{ Expenditures } & number of employees & 25,909 & 16,387 & 6,297 \\
\hline & bank's assets (PLN million) & 266,900 & $165,760.7$ & 40,003 \\
\hline \multirow{4}{*}{ Results } & value of deposits (PLN million) & 195,800 & 124,400 & 33,700 \\
\hline & value of credits (PLN million) & 190,400 & $118,662.9$ & 30,900 \\
\hline & number of clients & $8,982,000$ & $5,088,824$ & $2,461,377$ \\
\hline & capital adequacy ratio & $14.61 \%$ & $18.20 \%$ & $12.54 \%$ \\
\hline \multicolumn{5}{|c|}{ Year 2016} \\
\hline \multicolumn{2}{|r|}{ Specification } & PKO BP & Pekao & Alior \\
\hline \multirow{2}{*}{ Expenditures } & number of employees & 25,381 & 15,882 & 10,336 \\
\hline & bank's assets (PLN million) & 285,600 & $170,988.8$ & $61,209.5$ \\
\hline \multirow{4}{*}{ Results } & value of deposits (PLN million) & 205,100 & $136,229.3$ & 51,400 \\
\hline & value of credits (PLN million) & 200,600 & $123,660.5$ & 46,300 \\
\hline & number of clients & $9,199,000$ & $5,232,748$ & $3,505,685$ \\
\hline & capital adequacy ratio & $15.81 \%$ & $18.17 \%$ & $13.65 \%$ \\
\hline \multicolumn{5}{|c|}{ Year 2017} \\
\hline \multicolumn{2}{|r|}{ Specification } & PKO BP & Pekao & Alior \\
\hline \multirow{2}{*}{ Expenditures } & number of employees & 24,500 & 15,316 & 8,110 \\
\hline & bank's assets (PLN million) & 296,900 & 182,077 & 69,382 \\
\hline \multirow{4}{*}{ Results } & value of deposits (PLN million) & 222,524 & 146,898 & 57,655 \\
\hline & value of credits (PLN million) & 186,890 & 128,873 & 51,244 \\
\hline & number of clients & $9,497,700$ & $5,389,351$ & $3,472,431$ \\
\hline & capital adequacy ratio & $17.37 \%$ & $18.2 \%$ & $15.3 \%$ \\
\hline
\end{tabular}

Source: Author's own study based on the financial reports of the analysed banks for the years 2014-2017 (www 1; www 2; www 3). 


\section{An example of using the CCR-DEA method for analysing the technical efficiency of selected commercial banks in the years 2014-2017}

The technical efficiency of a bank in an expenditure-oriented model determines how much (proportionally) the expenditures should be reduced to achieve the same level of results. The measure of efficiency in a model thus defined involves finding the minimal value of the efficiency factor/coefficient/indicator of particular units, which allows for diminishing the expenditures in such a way that the level of effects remains the same. As mentioned above, measuring the technical efficiency requires building a CCR-DEA model, which is a linear programming problem. Therefore, using the data from Table 2, calculations were made using the Solver application of Microsoft Excel.

Using the CCR-DEA method, the calculations show that all the banks taking part in the analysis of technical efficiency displayed technical efficiency at the level of $100 \%$ or a value near $100 \%$ in each of the periods under analysis. The results are presented in Table 3.

Table 3. The results of measuring the technical efficiency of selected banks in the years 2014-2017 (with accuracy up to 15 digits after a separator)

\begin{tabular}{|c|c|c|c|}
\hline & PKO BP & Pekao SA & Alior Bank \\
\hline 2014 & 0.999999999999999 & 0.999999999999998 & 1.000000000000000 \\
\hline 2015 & 0.999999999999999 & 1.000000000000090 & 1.000000000000000 \\
\hline 2016 & 1.000000000000000 & 1.000000000000000 & 1.000000000000000 \\
\hline 2017 & 1.000000000000000 & 1.000000000000000 & 1.000000000000000 \\
\hline
\end{tabular}

Source: Author's own study based on the financial reports of the analysed banks for the years 2014-2017 (www 1; www 2; www 3).

In this view, it can be noticed that in the years 2014-2015, PKO Bank Polski, the largest commercial bank in Poland, reached almost 100\% of technical efficiency compared to the other units under analysis, similar to Pekao SA in 2014. However, these results are so close to number one that, thanks to a simultaneous growth of effects and expenditures, all of the analysed banks (including Alior Bank) keep their technical efficiency at the highest level.

The cost of acquiring Nordea Bank Polska SA by PKO BP SA related to the integration of these banks in the years 2013-2015 amounted to PLN 188 billion and was lower than expected in 2013. The personal costs (in this analysis, a derivative of expenditures in terms of numbers of employees) constituted $21 \%$ of all the integration costs (www 1) $)^{8}$. In 2016, the goals assumed before the fusion and involving a cost synergy amounting to PLN 153 million were reached. The acquisition by PKO BP strengthened the bank's competence in corporate banking and in the segment of

8 The main items of integration costs embraced the area of the migration of IT systems (over 47\%), marketing and communication $(6 \%)$, real estate $(5 \%)$, and others $(21 \%)$. 
wealthy clients. In addition, taking over a relatively large mortgage loan portfolio contributed to the development of mortgage banking'.

As shown above, the evaluation of the technical efficiency of commercial banks carried out using the CCR-DEA model facilitates their ranking and determining a benchmark of efficiency. This model, along with other adaptations of the DEA method (e.g. a result-oriented model), is extremely important in the process of decision-making, since it is possible to identify the areas of inefficiency and correct them later. Consequently, banks and other companies using this method can improve their results through the optimisation of using their resources.

The analysis conducted above indicates that all the analysed banks appear to be effective. The variables assumed for the model show that human resources and assets in these units are best related to the amount of deposits and credits based on security.

\section{Conclusions}

The DEA method is a management solution that helps with decision-making. Taking the results of this analysis into consideration, it can be stated that the efficiency of the banks under analysis - analysed according to specified criteria - remains on a stable and acceptable level. The variables for the DEA method assumed in the analysis are exemplary variables which can be expanded or changed in accordance with the literature and adapted to the current analytic requirements.

In future research, in addition to expenditures viewed as the number of employees and the assets of a bank, the costs of salaries (in the light of a growing pay-rise pressure) and operational costs (due to a high level of legal-regulation requirements imposed on banks and diminishing operational risks) should also be considered. On the effect side, the basic financial indicators (ROE, ROA, the leverage indicator, LCR, etc.) should be placed together. Moreover, the period of analysis should be extended to show the effects of fusions that may undergo remodelling over periods longer than three or four years.

Expanding the analysis is required to answer the question about the reasons for the growth of efficiency of commercial banks, namely to what extent that growth was supported by ownership changes in the sector, by regulations concerning capital adequacy demands imposed on banks by the supervision, by the requirements of Basel III, etc. It should also be considered that in the model employed here, constant returns to scale were assumed. Consequently, analysing decreasing returns to scale and increasing returns to scale was excluded.

9 In August 2014, PKO Bank Polski received permission from the Financial Oversight Commission to create PKO Bank Hipoteczny, which started operating in April 2015. 


\section{References}

Adamik, A. (red.). (2011). Ksztaltowanie konkurencyjności i przewagi konkurencyjnej małych i średnich przedsiębiorstw. Warszawa: C.H. Beck.

Capiga, M. (2009). Determinanty i pomiar efektywności działania banku. In: J. Harasim (red.), Konkurencyjność i efektywność działania banku - podejście zasobowe. Katowice: Wydawnictwo Akademii Ekonomicznej.

Czyżewski, A., \& Smędzik, K. (2010). Efektywność techniczna i środowiskowa gospodarstw rolnych w Polsce według ich typów i klas wielkości w latach 2006-2008. Roczniki Nauk Rolniczych, seria G, 97(3).

Domagała, A. (2007). Metoda Data Envelopment Analysis jako narzędzie badania względnej efektywności technicznej. Badania Operacyjne i Decyzje, 3-4.

Golany, B., \& Roll, Y. (1989). An application procedure for DEA. Omega, 17(3).

Gospodarowicz, A. (2002). Analiza i ocena banków oraz ich oddziałów. Wrocław: Wydawnictwo Akademii Ekonomicznej.

Gradoń, W. (2016). Pomiar wartości banku. In: M. Capiga, W. Gradoń, G. Szustak (red.), Kreowanie wartości banku. Warszawa: Difin.

Guzik, B. (2009). Podstawowe możliwości analityczne modelu CCR-DEA. Badania Operacyjne i Decyzje, 1.

Jonek-Kowalska, I., \& Zieliński, M. (2017). CSR Activities in the Banking Sector in Poland. In: K.S. Soliman (ed.), Education Excellence and Innovation Management through Vision 2020: From Regional Development Sustainability to Global Economic Growth. Proceedings of the $29^{\text {th }}$ International Business Information Management Association Conference, International Business Information Management Association, Vienna.

Kopiński, A., \& Porębski, D. (2015). Próba oceny efektywności banków komercyjnych za pomocą metody DEA. Annales Universitatis Mariae Curie-Sklodowska, sectio H-Oeconomia, XLIX(4).

Marek, S., \& Białasiewicz, M. (red.). (2008). Podstawy nauki o organizacji. Warszawa: Polskie Wydawnictwo Ekonomiczne.

Michalak, A. (2016). The cost of capital in the efficiency assessment of financial management in accompany. Quarterly Journal Oeconomia Copernicana, 7(2).

Nawrocki, T., \& Jabłoński, B. (2011). Inwestowanie na rynku akcji. Jak ocenić potencjat rozwojowy spótek notowanych na GPW w Warszawie. Warszawa: CeDeWu.

Nawrocki, T.L. (2015). The use of fuzzy logic in the enterprises business efficiency assessment. In: T. Dudycz, G. Osbert-Pociecha, B. Brycz (red.), The Essence and Measurement of Organizational Efficiency. Springer Proceedings in Business and Economics.

Nowak, K., \& Matuszyk, A. (2014). Analiza możliwości zastosowania metody DEA w modelach scoringowych. Studia Ekonomiczne /Uniwersytet Ekonomiczny w Katowicach, 186(1), 113-126.

Olesen, O.B., Petersen, N.Ch., \& Podinovski, V.V. (2017). Efficiency measures and computational approaches for data envelopment analysis models with ratio inputs and outputs. European Journal of Operational Research, 261(2), 640-655. doi:10.1016/j.ejor.2017.02.021

Pyka, A. (2015). Podmioty systemu finansowego. Banki komercyjne. In: H. Zadora (red.), Finanse. Kategorie - zjawiska i procesy - podmioty. Warszawa: Difin.

Pyka, I., Cichy, J., Nocoń, A., \& Pyka, A. (2018). Repolonizacja banków w Polsce. Przestanki, założenia i dylematy zmian wtasnościowych. Warszawa: Difin.

Stoła, E. (2011). Efektywność techniczna a efektywność finansowa banków komercyjnych. Zeszyty Naukowe Uniwersytetu Szczecińskiego. Finanse, Rynki Finansowe, Ubezpieczenia, 37, 141-152.

Sufian, F., \& Habibullah, M.S. (2009). Determinants of bank profitability in a developing economy: Empirical evidence from Bangladesh. Journal of Business Economics and Management, 10(3), 207-217.

Szelągowska, A., \& Posacka K. (2006). Zastosowanie analizy regresji w ocenie konkurencyjności wybranych banków komercyjnych w Polsce w latach 1996-2004. Zeszyty Naukowe Wyższej Szkoły Informatyki w Lodzi, Teoria i Zastosowanie Informatyki, 5(1), 137-146. 
Pobrane z czasopisma Annales $\mathrm{H}$ - Oeconomia http://oeconomia.annales.umcs.pl Data: 26/04/2023 10:02:27

Raporty finansowe Alior Banku SA za lata 2014, 2015, 2016.

Raporty finansowe PeKaO SA za lata 2014, 2015, 2016.

Raporty finansowe PKO BP SA za lata 2014, 2015, 2016.

[www 1] https://www.pkobp.pl

[www 2] https://www.aliorbank.pl/

[www 3] https://pekao.com.pl 